\title{
Ultrastructural Morphometry of Renal Tubule Epithelium in Rats Treated with Conventional Amphotericin B Deoxycholate or Amphotericin B Colloidal Dispersion
}

\section{LAUSCHOVÁ ${ }^{1}$, L. KREJČÍŘOVÁ ${ }^{1}$, D. HORKÝ ${ }^{1}$, M. DOUBEK ${ }^{2}$, J. MAYER ${ }^{2}$, J. DOUBEK ${ }^{3}$}

\begin{abstract}
${ }^{1}$ Department of Histology and Embryology, Medicine Faculty Masaryk University Brno, Czech Republic, 2Department of Internal Medicine - Haematooncology, Masaryk University Hospital Brno, Czech Republic, ${ }^{3}$ Department of Physiology and Pathophysiology, Faculty of Veterinary Medicine, University of Veterinary and Pharmaceutical Sciences Brno, Czech Republic
\end{abstract}

Received November 24, 2003

Accepted June 17, 2004

\begin{abstract}
Lauschová I., L. Krejčířová, D. Horký, M. Doubek, J. Mayer, J. Doubek: Ultrastructural Morphometry of Renal Tubule Epithelium in Rats Treated with Conventional Amphotericin B Deoxycholate or Amphotericin B Colloidal Dispersion. Acta Vet. Brno 2004, 73 : 165-169.

The aim of our study was to compare the nephrotoxicity of AmB deoxycholate and ABCD in rat model. The effects of AmB and ABCD on ultrastructure of the epithelium of proximal and distal tubules in rat kidney were studied and evaluated by using of morphometric and statistical methods. Two groups of rats $(n=3)$ were used: rats of Group 1 were treated with AmB deoxycholate (Amphotericin B Squibb ${ }^{\circledR}$, Bristol-Myers Squibb; $4 \mathrm{mg} / \mathrm{kg}$ of body weight daily for a period of 14 days), Group 2 included animals, to which ABCD was given (Amphocil ${ }^{\circledR}$, Torrex Pharma; 12 $\mathrm{mg} / \mathrm{kg}$ of body weight daily for a period of 14 days). Tissue samples from kidney were taken and processed for transmission electron microscopic (morphometric) study. It was observed that AmB caused more than ABCD morphological changes in cytoplasm of the epithelial cells: damage of mitochondria, vacuolation of cytoplasm, and increased values of volume density of peroxisomes. However, we did not observe significant differences in morphology and density of lysosomes, pinocytotic vesicules, lipid droplets, Golgi apparatus and granular endoplasmic reticulum. It seems that proximal tubules are more sensitive to nephrotoxic influence of both formulas than distal tubules. In the rat, both $\mathrm{AmB}$ and $\mathrm{ABCD}$ causes damage to renal tubuli. AmB causes more severe damage than ABCD. Morphological and statistical results of our study did not reveal any significant differences (except in volume density of peroxisomes). From the point of view of nephrotoxic effects on the renal tubule epithelium AmB is approximately comparable to ABCD.
\end{abstract}

TEM, proximal tubule, distal tubule, peroxisomes, mitochondria, lysosomes, pinocytotic vesicules, granular endoplasmic reticulum

Amphotericin B deoxycholate (AmB) is used for efficacious medication of systemic fungal infections in spite of the fact that nephrotoxic effects were mentioned by some authors (Bodey (ed) 1993; Mayer et al. 1999; Costa and Nucci 2001; Fisher et al. 1989). Amphotericin B colloidal dispersion (ABCD), amphotericin B lipid complex (ABLC), liposomal $\mathrm{AmB}$, in addition to the conventional $\mathrm{AmB}$, are used in the clinics. $\mathrm{ABCD}, \mathrm{ABLC}$, and liposomal AmB seem to be more gentle to kidney parenchyma and its functions than AmB (Prentice et al. 1997; Walsh et al. 1998 and 1999; White et al. 1998). Unfortunately, these new formulas of AmB are considerably more expensive (Costa and Nucci 2001).

The majority of clinical references concentrate on the functional evaluation of kidneys; morphological aspects are studied as a matter of peripheral importance. Light microscopy is mostly used and necrosis of the epithelial cells is repeatedly detected. The effects of both mentioned drugs on rat kidney parenchyma were studied and compared on ultramicroscopic level in our previous study (Krejčířová et al. 2003). Vacuolation of cytoplasm and some 
mitochondria, presence of damaged mitochondria, increased number of peroxisomes (especially after AmB), dilated extracellular space between epithelium and basal lamina in basal labyrinth, reduction of microvilli in brush border were observed and described in this study. The aim of this evaluation was to review our findings (Krejčířová et al. 2003), especially aimed at cellular organelles using stereological and statistical methods.

\section{Materials and Methods}

Male laboratory rats (pathogen-free; source Anlab, Prague, Czech Republic) 265-380 g body weight were used. They were individually housed in metabolic cages for urine collection during the study. The adaptation time to these new conditions was 7 days for each experiment. Rats were maintained on standard rat chow ad libitum. Water was not restricted. The Ethics Committee of the Faculty of Veterinary Medicine, University of Veterinary and Pharmaceutical Sciences, Brno, approved the studies. Two groups were established: group $1(n=3)$ rats treated with AmB deoxycholate (Amphotericin B Squibb ${ }^{\circledR}$, Bristol-Myers Squibb; $4 \mathrm{mg} / \mathrm{kg}$ of body weight daily for a period of 14 days), group 2 ( $\mathrm{n}=3$ ) rats treated with $\mathrm{ABCD}$ (Amphocil ${ }^{\circledR}$, Torrex Pharma; $12 \mathrm{mg} / \mathrm{kg}$ of body weight daily for a period of 14 days). Rats received $\mathrm{AmB}$ or $\mathrm{ABCD}$ ip. Water for injections (Bieffe Medital) served as a vehicle for the dilution of both formulas.

Animals were killed $24 \mathrm{~h}$ after administration of the last dosis of AmB or ABCD. They were decapitated while under anesthesia, and kidneys were removed. Tissue samples from kidneys were taken lege artis and processed for transmission electron microscopic study.

Stereometric evaluation of the above-mentioned material was done and observed values of volume density of selected organelles in epithelial cells of renal tubules (proximal and distal tubules) were statistically analysed. Embedded tissue blocks were cut in three layers. Contrasted ultrathin sections were followed and photographed in transmission electron microscope Morgagni 286D (FEI) at primary magnification 4,000 $\times$. Negatives were screened on regular 100-point grid of modified reading apparatus Carl Zeiss (Jena) (Weibel 1969) and secondary magnified, so the total magnification was $28,000 \times$. Volume densities of organelles observed in the epithelial cells of proximal and distal tubules (nuclei, mitochodria, Golgi apparatus, granular endoplasmic reticulum, pinocytotic vesicles, vacuoles, lipid droplets, peroxisomes and lysosomes) were counted from the screen. Statistical analysis included the calculation of mean values of volume density, standard deviation, standard error mean. Simple analysis of variation (Student's test) was used for determination of significance of differences at $p<0.05$ and $p<0.01$.

Table 1

Volume densities of cell organelles

\begin{tabular}{|c|c|c|c|}
\hline & \multicolumn{2}{|c|}{$\mathrm{VD}(\%) \pm \mathrm{SD}$} \\
\hline & & proximal tubules & distal tubules \\
\hline \multirow[t]{2}{*}{ Nuclei } & $\mathrm{AmB}$ & $12.58 \pm 3.84$ & $13.54 \pm 2.60$ \\
\hline & $\mathrm{ABCD}$ & $8.32 \pm 2.67$ & $13.83 \pm 1.89$ \\
\hline \multirow[t]{2}{*}{ Mitochondria } & $\mathrm{AmB}$ & $13.42 \pm 0.95$ & $14.70 \pm 4.82$ \\
\hline & $\mathrm{ABCD}$ & $16.86 \pm 2.09$ & $16.28 \pm 0.67$ \\
\hline \multirow[t]{2}{*}{ Golgi apparatus } & $\mathrm{AmB}$ & $0.71 \pm 0.27$ & $0.55 \pm 0.06$ \\
\hline & $\mathrm{ABCD}$ & $0.57 \pm 0.18$ & $0.68 \pm 0.41$ \\
\hline \multirow{2}{*}{$\begin{array}{l}\text { Granular endoplasmic } \\
\text { reticulum }\end{array}$} & $\mathrm{AmB}$ & $2.08 \pm 0.42$ & $2.55 \pm 0.79$ \\
\hline & $\mathrm{ABCD}$ & $1.70 \pm 0.05$ & $1.92 \pm 0.19$ \\
\hline \multirow[t]{2}{*}{ Pinocytotic vesicles } & $\mathrm{AmB}$ & $3.25 \pm 0.39$ & $2.48 \pm 0.29$ \\
\hline & $\mathrm{ABCD}$ & $3.33 \pm 0.35$ & $2.33 \pm 0.06$ \\
\hline \multirow[t]{2}{*}{ Lipid droplets } & $\mathrm{AmB}$ & $0.67 \pm 0.35$ & $0.51 \pm 0.12$ \\
\hline & $\mathrm{ABCD}$ & $0.78 \pm 0.52$ & $0.04 \pm 0.04$ \\
\hline \multirow[t]{2}{*}{ Vacuoles } & $\mathrm{AmB}$ & $4.77 \pm 1.83$ & $2.48 \pm 0.29$ \\
\hline & $\mathrm{ABCD}$ & $4.97 \pm 3.94$ & $0.36 \pm 0.19 *$ \\
\hline \multirow[t]{2}{*}{ Peroxisomes } & $\mathrm{AmB}$ & $1.05 \pm 0.45 *$ & $1.33 \pm 0.81$ * \\
\hline & $\mathrm{ABCD}$ & $0.36 \pm 0.01$ & $0.32 \pm 0.15$ \\
\hline \multirow[t]{2}{*}{ Lysosomes } & $\mathrm{AmB}$ & $0.81 \pm 0.47$ & $0.93 \pm 0.48$ \\
\hline & $\mathrm{ABCD}$ & $0.61 \pm 0.39$ & $0.34 \pm 0.17$ \\
\hline
\end{tabular}

Abbreviations used in the table

AmB - amphotericin B deoxycholate, ABCD - amphotericin B colloidal dispersion, Dt - distal tubule, Pt proximal tubule, $\mathrm{VD}(\%) \pm \mathrm{SD}$ - volume density and standard deviation,

* - statistical significance 


\section{Results}

Volume density of the cell nuclei (Table 1) in both studied types of renal tubules had not been significantly different after administration of $\mathrm{AmB}$ or $\mathrm{ABCD}$. The mitochondria did not show significant differences in volume density after administration of $\mathrm{AmB}$ or $\mathrm{ABCD}$, but morphological signs of their damage, more after AmB than after ABCD, were observed. These signs were represented by occurrence of enlarged mitochondria (sometimes to about $2.5 \mu \mathrm{m}$ in diameter - megamitochondria), some mitochondria showed non-distinct inner structure or loosed their cristae and were vacuolated. Due to these findings, evaluation of mitochondria was done in more details. Percentage of damaged mitochondria was established from total number of found mitochondria and received values were statistically evaluated: in proximal tubules it was $46 \%( \pm 3.12)$ after AmB and 21\% ( \pm 1.08$)$ after ABCD; in distal tubules it was 35\% ( \pm 2.40$)$ after AmB and 17\% ( \pm 1.56$)$ after ABCD. Significantly higher values of damaged mitochondria $(p<0.01)$ were recorded in group of animals to which AmB was given. No significant differences were observed in volume density of Golgi apparatus, rough endoplasmic reticulum, pinocytotic vesicles, lipid droplets and lysosomes in the cells of renal tubules after administration of both mentioned formulas. A significant difference $(p<0.05)$ was observed in density of vacuoles. The value was significantly lower in epithelial cells of distal tubules in animals after ABCD compared with AmB and values observed in proximal tubules after administration of both formulas. Significantly higher values of peroxisomes density $(p<0.05)$ were found in group of animals, to which AmB was given. These findings were in both types of tubules. Values of volume density of all studied organelles are presented in Table 1.

\section{Discussion}

It is known that AmB belongs to nephrotoxic drugs and its effects on renal functions were described by many authors (A ron s on et al. 1979; Cheng et al. 1982; Kavlock et al. 1985; Zager et al. 1991; Inselmann et al. 2003 and others). According to Terrel and Hughes (1992) or Zhang et al. (2002), AmB acts by binding to sterols, ergosterol in fungal membranes or cholesterol in biological membranes of mammalian cells. Also $\mathrm{Ng}$ et al. (2003) believe that AmB and other polyene antibiotic-induced renal toxicity is mediated by the drug anchoring to cholesterol within the mammalian cell membrane, resulting in pore formation, abnormal electrolyte flux, decrease in adenosine triphosphate, and eventually a loss of cell viability.

$\mathrm{ABCD}, \mathrm{ABLC}$ and liposomal AmB are considered to be more gentle to kidney parenchyma and its functions (Prentice et al. 1997; Walsh et al. 1998 and 1999; White et al. 1998). In the view of volume density measurement, values of mitochondria in animals treated with $\mathrm{AmB}$ or $\mathrm{ABCD}$ did not show any statistically significant differences. But there is important to mention a morphological appearance of these organelles. Generally, more or less mitochondria were damaged after an administration of not only AmB, but also ABCD. The ultrastructural signs of their damage were represented by an occurrence of enlarged mitochondria (sometimes to about $2.5 \mu \mathrm{m}$ in diameter - megamitochondria), some of them showed non-distinct inner structure or loosed their cristae. Some of such mitochondria contain large vacuole inside of their matrix. Because the giant mitochondria are voluminous, their presence in the cytoplasm caused that the values of volume density were relatively high, while mitochondria were usually only sparsely represented in the cells. It was observed that $35-46 \%$ of mitochondria present in the epithelium of tubules in group of animals given AmB were damaged, while in group given ABCD damaged mitochondria represented $17-21 \%$ from their total number. Higher values of both these ranges were observed in proximal tubules. Probably a higher sensitivity of the epithelium of proximal tubules is manifested. 
Insignificantly higher values of pinocytotic vesicle and lysosome density in epithelial cells of renal tubules may show the fact that the absorptive function of tubules need not be irreversibly affected after neither AmB nor ABCD administration. It was observed that nephrotoxicity of conventional $\mathrm{AmB}$ can be reduced after some nephroprotective measures, like vigorous hydration and ion supplementation proportionally to their loss via the kidney (Mayer et al. 1999; Mayer et al. 2002). The difference of values of volume density of vacuoles observed in proximal tubules was insignificantly higher for both drugs given, while in distal tubules there was a significant difference between values after AmB and ABCD. It can be assumed, that the different values in distal tubules are not the results of influence of these formulas or that the epithelium of proximal tubules is more sensible to both formulas than the cells in distal tubules. Significantly higher values of peroxisomes density after AmB administration can be explained as the result of increased detoxicating activity in the cells. The other followed organelles (nucleus, endoplasmic reticulum, Golgi apparatus, pinocytotic vesicles) did not show any statistically significant differences.

\section{Subcelulární morfometrie epitelu v ledvinných tubulech laboratorního potkana po podání konvenčního amphotericin B deoxycholátu nebo jeho koloidní disperze}

Cílem práce bylo porovnat vliv obou lékových forem na základě ultrastrukturního studia a statistického vyšetření změn $\mathrm{v}$ epitelu proximálních a distálních kanálků v ledvině laboratorního potkana. Byly použity dvě skupiny zvířat. První skupině byl podáván AmB deoxycholát (Amphotericin B Squibb ${ }^{\circledR}$, Bristol-Myers Squibb; $4 \mathrm{mg} \cdot \mathrm{kg} \cdot \mathrm{d}^{-1}$ ) a 2 . skupině ABCD (Amphocil ${ }^{\circledR}$, Torrex Pharma; $12 \mathrm{mg} \cdot \mathrm{kg} \cdot \mathrm{d}^{-1}$ ) po dobu 14 dní. Odebrané vzorky tkání byly zpracovány pro transmisní elektronovou mikroskopii a morfometrické měření.

V ledvině potkana bylo zjištěno, že oba preparáty (AmB však větší měrou než $A B C D)$ způsobují morfologické změny v cytoplazmě epitelových buněk: poškození mitochondrií, vakuolizaci cytoplazmy a zvýšení hodnot objemové denzity peroxisomů. Tyto změny byly hojnější a výraznější v proximálních tubulech; epitel distálních tubulů vykazoval větší rezistenci výši působení obou lékových forem.

\section{Acknowledgement}

The study was supported by grant No. NL 6514-3/2001 of the Internal Grant Agency, Ministry of Health, Czech Republic.

\section{References}

ARONSON, PS, HAYSLETT, JP, KASHGARIAN, M 1979: Dissociation of proximal tubular glucose and Na+ reabsorption by amphotericin B. Am J Physiol - Renal Physiol 236: F392-F397

BODEY, GP (ed) 1993: Candidiasis: pathogenesis, diagnosis and treatment. Raven Press, New York, 422 p.

CHENG, JT, WITTY, RT, ROBINSON, RR, YARGER, WE 1982: Amphotericin B nephrotoxicity: increased renal resistance and tubule permeability. Kidney Int 22: 626-633

COSTA, S, NUCCI, M 2001: Can we decrease amphotericin nephrotoxicity? Current Opin Crit Care 7: 379-383

FISHER, MA, TALBOT, GH, MAISLIN, G, McKEON, BP, TYNAN, KP, STROM, BL 1989: Risk factors for amphotericin B-associated nephrotoxicity. Am J Med 87: 547-552

INSELMANN, G, BALASCHKE, M, HEIDEMANN, HT 2003: Enzymuria following amphotericin B application in the rat. Mycoses 46: 5-6

KAVLOCK, RJ, REHNBERG, BF, ROGERS, EH 1985: Amphotericin B - and folic acid- nephropaties in developing rats. Toxicol Appl Pharmacol 81: 407-415

KREJČÍROVÁ, L, LAUSCHOVÁ, I, DOUBEK, M, HORKÝ, D, MAYER, J, DOUBEK, J, 2003: Changes of rat kidneys after administration of Amphotericin B colloidal disperion and conventional Amphotericin B deoxycholate. Morphological observation. Scripta medica (Brno) 76: 257

MAYER, J, DOUBEK, M, VORLÍČEK, J 1999: Must we really fear toxicity of conventional amphotericin B in oncological patients? Support Care Cancer 7: 51-56

MAYER, J, DOUBEK, M, DOUBEK, J, HORKÝ, D, SCHEER, P, ŠTĚPÁNEK, M 2002: Reduced nephrotoxicity of conventional amphotericin B therapy after minimal nephroprotective measures: animal experiments and clinical study. J Infect Dis 186: 379-388 
NG, AW, WASAN, KM, et al. 2003: Development of liposomal polyene antibiotics: an historical perspective. J Pharm Pharm Sci 6: 67-83

PRENTICE, HG, HANN, IM, HERBRECHT, R, AOUN, M, KVALOY, S, CATOVSKY, D, PINKERTON, CR, SCHEY, SA, JACOBS, F, OAKHILL, A, STEVENS, RF, DARBYSHIRE, PJ, GIBSON, BES 1997: A randomized comparison of liposomal versus conventional amphotericin B for the treatment of pyrexia of unknown origin in neutropenic patients. Br J Haematol 98: 711-718

TERREL, CL, HUGHES, CE 1992: Antifungal agents used for deep-seated mycotic infections. Mayo Clin. Proc. 67: 69-91

WALSH, TJ, HIEMENZ, JW, SEIBEL, NL, PERFECT, JR, HORWITH, G, LEE, L, SILBER, JL, DiNUBILE, MJ, REBOLI, A, BOW, E, LISTER, J, ANAISSIE, EJ 1998: Amphotericin B lipid complex for invasive fungal infections: analysis of safety and efficacy in 556 cases. Clin Infect Dis 26: 1383-1396

WALSH, TJ, FINBERG, RW, ARNDT, C, HIEMENZ, J, SCWARTZ, C, BODENSTEINER, D, PAPPAS, P, SEIBEL, R, GREENBERG, N, DUMMER, S, SCHUSTER, M, HOLCENBERG, JS 1999: Liposomal amphotericin B for empirical therapy in patients with persistent fever and neutropenia. N Engl J Med 340: 764771

WEIBEL, ER 1969: Stereological principles for morphometry in electron microscopic cytology. Int Rev Cytol 26: 235-302

WHITE, MH, BOWDEN, RA, SANDLER, ES, GRAHAM, ML, NOSKIN, GA, WINGARD, JR, GOLDMAN, M, van BURIK, JA, McCABE, A, LIN, JS, GURWITH, M, MILLER, CB 1998: Randomized, double-blind clinical trial of amphotericin B colloidal dispersion vs. amphotericin B in the empirical treatment of fever and neutropenia. Clin Infect Dis 27: 296-302

ZAGER, RA, BREDL, CR, SCHIMPF, BA 1991: Direct amphotericin B - mediated tubular toxicity: assesment of selected cytoprotective agents. Kidney Inter 41: 1588-1594

ZHANG, L, ZHANG, Y, ZHOU, Y, AN, S, ZHOU, Y, CHENG, J 2002: Response of gene expression in Saccaromyces cerevisiae to amphotericin B and nistatin by microarrays. J Antimicrob. Chemother. 49: 905-915 